\title{
The Gum Creek Cluster: Protohistoric Caddo Sites in the Little Cypress Creek Basin, ca. 1670-1720
}

Timothy K. Perttula

Heritage Research Center, Stephen F. Austin State University

Bo Nelson

Heritage Research Center, Stephen F. Austin State University

Follow this and additional works at: https://scholarworks.sfasu.edu/ita

Part of the American Material Culture Commons, Archaeological Anthropology Commons, Environmental Studies Commons, Other American Studies Commons, Other Arts and Humanities Commons, Other History of Art, Architecture, and Archaeology Commons, and the United States History Commons

Tell us how this article helped you.

This Article is brought to you for free and open access by the Center for Regional Heritage Research at SFA ScholarWorks. It has been accepted for inclusion in Index of Texas Archaeology: Open Access Gray Literature from the Lone Star State by an authorized editor of SFA ScholarWorks. For more information, please contact cdsscholarworks@sfasu.edu. 


\section{The Gum Creek Cluster: Protohistoric Caddo Sites in the Little Cypress Creek}

Basin, ca. 1670-1720

\section{Creative Commons License}

\section{(c) (1) (8)}

This work is licensed under a Creative Commons Attribution-NonCommercial 4.0 International License 


\section{THE GUM CREEK CLUSTER: PROTOHISTORIC CADDO SITES IN THE LITTLE CYPRESS CREEK BASIN, ca. 1670-1720}

\section{Timothy K. Perttula and Bo Nelson}

The Gum Creek cluster represents a group of contemporaneous Caddo sites in the Little Cypress Creek basin of East Texas (Figure 1) that were apparently occupied between ca. A.D. 1670-1720. These sites are closely affiliated with the Titus phase (see Perttula 2005) and may represent some of the very latest occupied Titus phase settlements in the Cypress Creek basin.

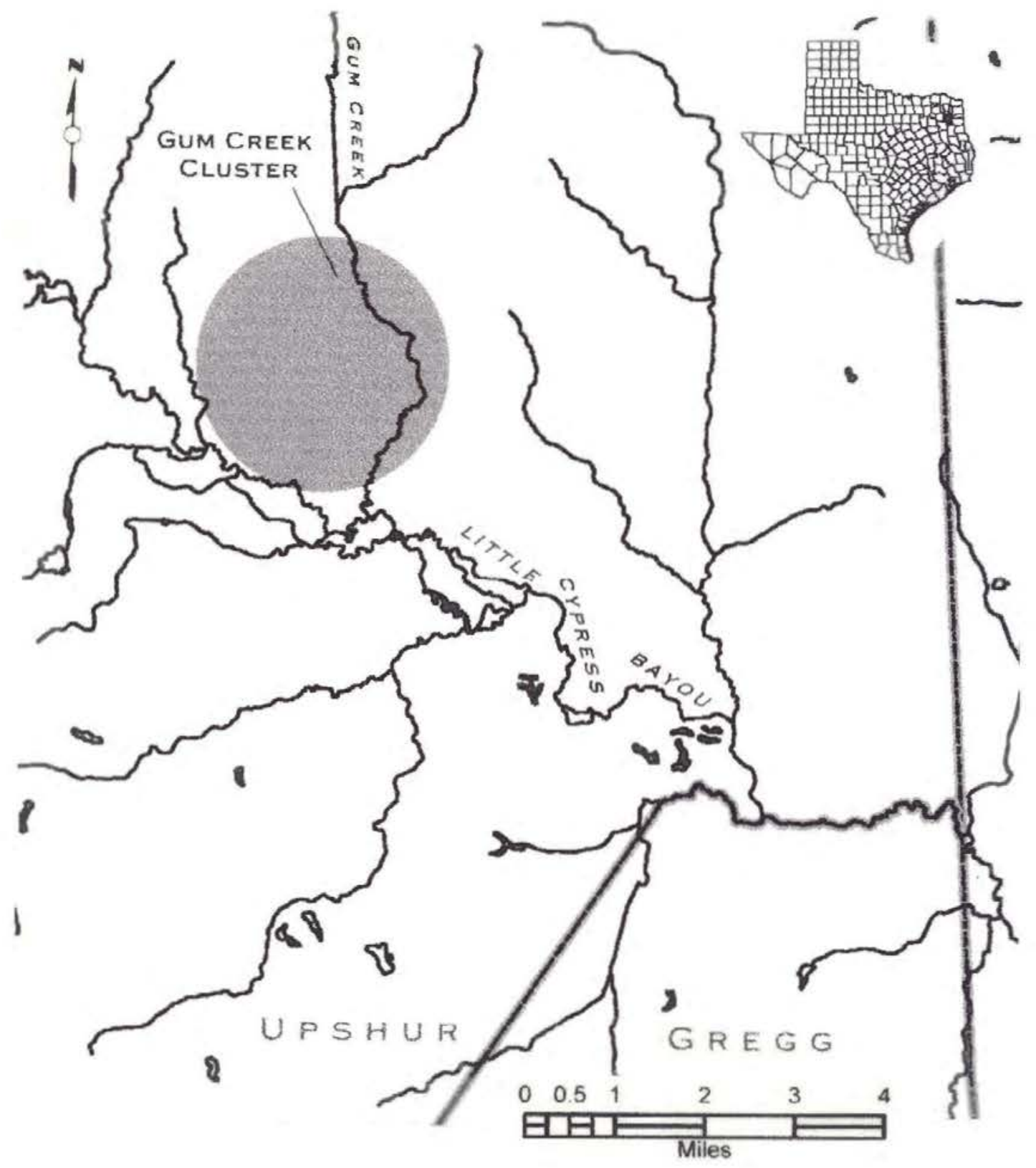

Figure 1. General area of the Gum Creek cluster in Upshur County, Texas. 
The Gum Creek cluster Caddo sites were excavated by Buddy Calvin Jones in the 1950 s and 1960 s, but were never reported by him during his lifetime. After his death, his vessel collection and other artifacts were documented by Perttula (2006a), with the able assistance of Bo Nelson and Bobby Gonzalez, and at that point it became clear that a certain number of excavated Caddo cemeteries in the Little Cypress Creek basin - the Gum Creek area specifically - had a distinctive artifact assemblage (especially in the form and decoration of certain vessels) that sometimes occurred in association with a few European trade goods. Caddo sites with European trade goods are otherwise very rare (see Figure 1, Perttula and Middlebrook, this volume) in the Big and Little Cypress Creek basins, and it seems likely that most of the aboriginal Caddo populations had vacated the area by the very end of the $17^{\text {th }}$ century. Those few sites that are left, such as the Gum Creek cluster and various sites along Caney Creek and Stouts Creek in Wood and Hopkins counties, Texas, may hold one of the keys in understanding this rapid abandonment of an area of East Texas occupied by Caddo peoples for many centuries.

\section{Artifact Assemblages in Gum Creek Cluster sites}

The temporal and cultural relationship between the Gum Creek cluster and the Titus phase is clear from the occurrence of Talco arrow points and Ripley Engraved vessels with the pendant triangle motif (Table 1). These types of artifacts are typically seen in post-A.D. 1600 contexts in Titus phase components. More distinctive fine ware vessels include Simms Engraved and Taylor Engraved vessels, including spool-necked bottles (Figure 1e); double-tiered engraved bowls (Figure 1c-d), including one from the Herbert Taft site with suspension holes; Hodges or Natchitoches Engraved shouldered bowls or jars with double sets of suspension holes (Figure 1a-b), and inverted rim Womack Engraved, var. Gum Creek carinated bowls (Figure 1f). Utility ware vessels include Cass Appliqued and Harleton Appliqued jars.

Table 1. Artifacts characteristic of Gum Creek cluster sites, Upshur County, Texas.

Talco arrow points

Ripley Engraved with pendant triangle motif

Cf. Womack Engraved, var. Gum Creek

Cass Appliqued jars

Taylor Engraved and Hodges Engraved spool-necked bottles

Keno Trailed

Simms Engraved, including Simms Engraved, var. Darco

Chalice forms

Natchitoches Engraved

Glass beads

Hawk bell, var. Flushloop 


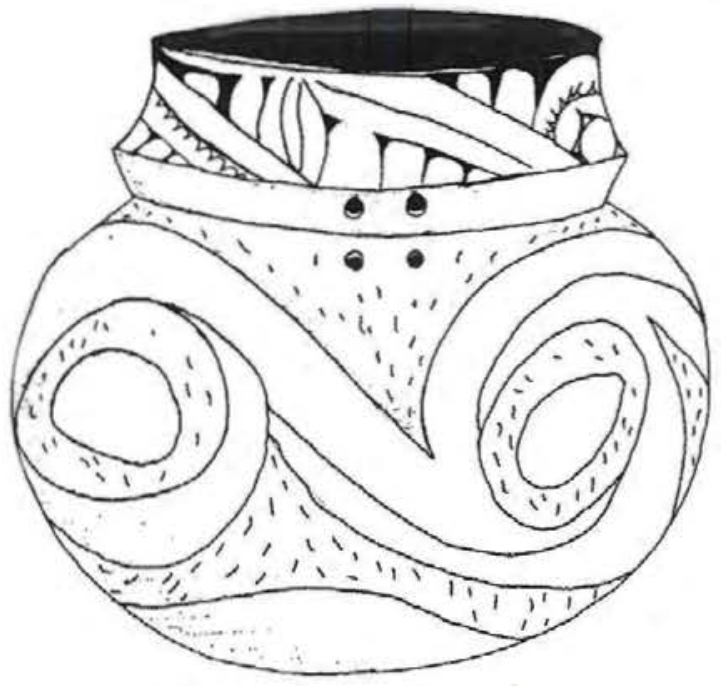

Figure 34.3. 6. U.C.

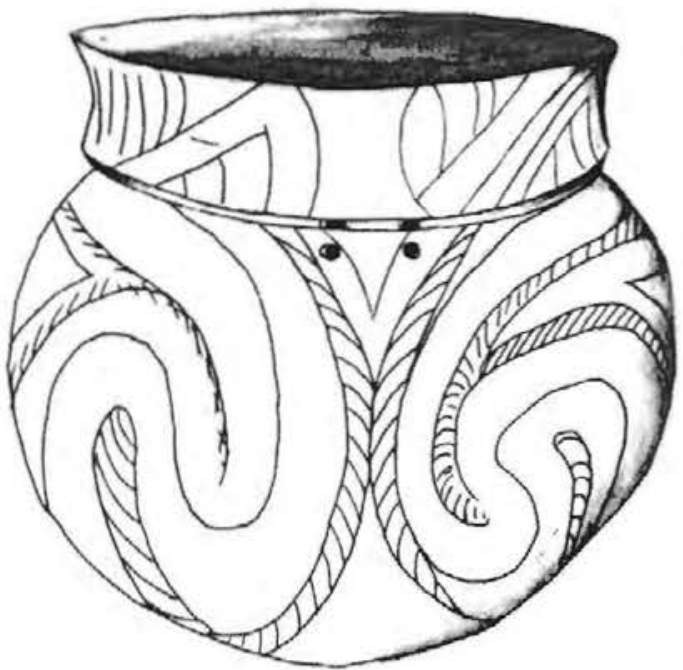

Figure 336. $40 \mathrm{TS}$.
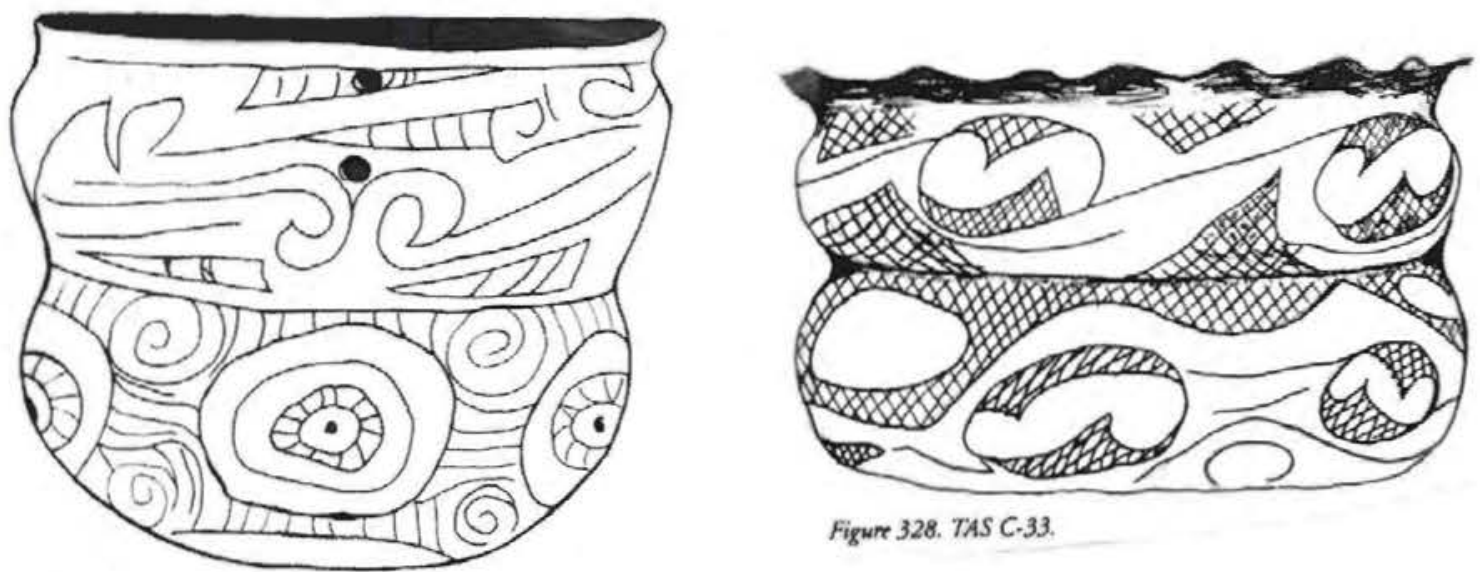

Figure 328. TAS C.33.

Figure 335. 5 TS.
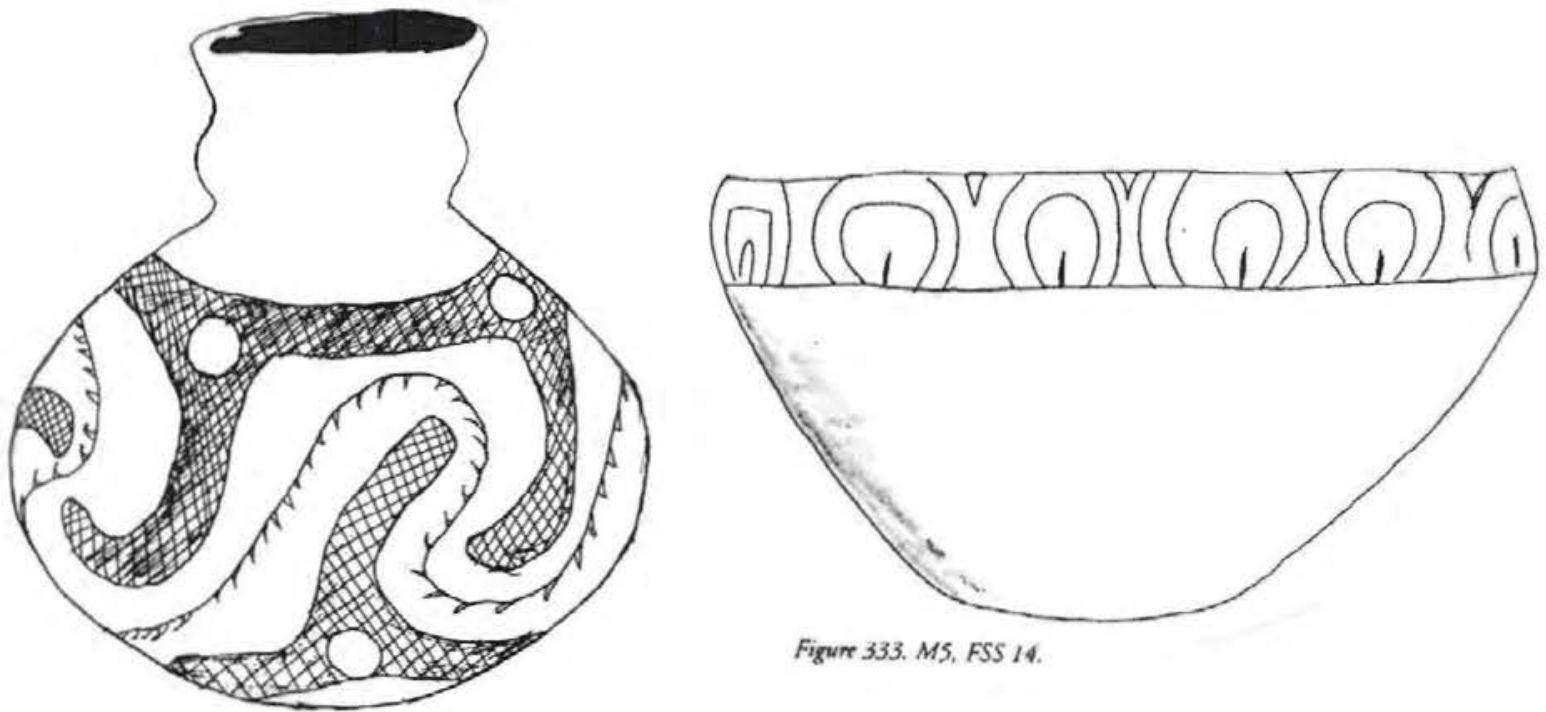

Figure 333. MS, FSS 14 .

Figure 338. PS, B-3 19

Figure 1. Gum Creek cluster vessels: a, d, possibly Henry Spencer site; b-c, Herbert Taft site; e, Patton/Pea Patch (41HS825); f, Frank Smith site. 
The European trade goods found by Jones in the Gum Creek cluster include glass beads from the Enis Smith (41UR317) and Henry Williams (41UR318) sites, and a var. Flushloop hawkbell from Henry Williams. The hawkbell is a common $17^{\text {th }}$ and $18^{\text {th }}$ century trade item of the French to Native Americans. The glass beads from the Enis Smith site are large white, red, and blue colors, and the predominance of large bead sizes suggest they are from late $17^{\text {th }}$ to early $18^{\text {th }}$ century contexts (Perttula 2005: Table 2). Conversely, at the Henry Williams site, the beads include large blue, red, and white colors, small to medium-sized blue, white, and red glass beads, as well as large Cornaline d'aleppo beads. The latter bead variety - commonly seen on Caddo sites - seems to be found on Caddo sites dating from ca. A.D. 1700-1760, suggesting that the Henry Williams site was occupied somewhat later in time than the Enis Smith site. This inference is also supported by the increased frequency of small and medium-sized beads, as they only become prominent in Caddo bead assemblages dating after A.D. 1700.

\section{Sites in the Gum Creek Cluster}

We currently recognize six sites as components of the Gum Creek cluster: Henry Spencer (4IUR315), Frank Smith, Enis Smith (41UR317), Henry Williams (4IUR318), Starr (4IUR319), and Herbert Taft (41UR320). The Sword site (4IUR208) may also have a late $17^{\text {th }}$ century component associated with these Gum Creek cluster sites, and the W-S site (4ITT741) on Swauano Creek has many of the same vessel forms and styles of decorated fine ware vessels (Perttula 2006b:14).

Jones excavated Caddo burials at each of these sites. At the Henry Spencer site, Jones' notes indicate that as many as 125 burials were excavated there, although not all of them by Jones (Perttula 2006a:4). Jones' notes also mention excavations he conducted in a midden area at the Henry Spencer site, and it is likely that each of these Gum Creek cluster sites also had associated habitation areas.

We list below the range and variety of artifacts recovered in mortuary contexts from the six Gum Creek cluster sites in the Little Cypress Creek basin (see Perttula 2006a for further details). We have deliberately not quantified the frequency of these various artifacts because of some question about the provenience of some specimens in the Jones collection as well as uncertainty that all of the artifacts Jones recovered from these sites were available for documentation during our 1999 documentation effort:

\section{Enis Smith (4IUR317, see Perttula 2006a:22-33)}

Glass beads (white, red, and blue, large size, late $17^{\text {th }}$-early $18^{\text {th }}$ century)

Talco points

Ripley Engraved

Womack Engraved with semi-circles (Figure 2)

Bailey Engraved

Brushed jar 


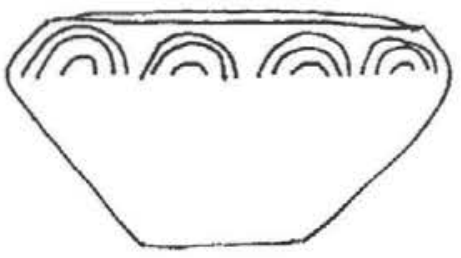

possible Womack

Engraved, Enis

Smith site (41UR317)

deep bowl and short inverted rim (Frank Smith site)

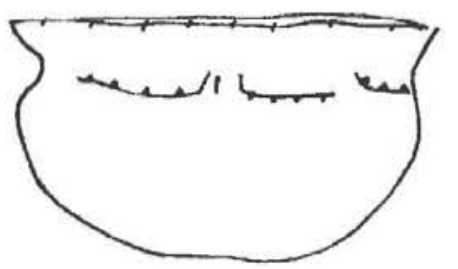

Simms Engraved, var. Darco

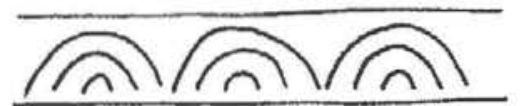

deep bowl and short inverted rim

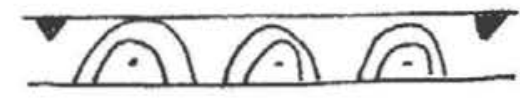

engraved semi-circle and small pendant triangles, Womack Engraved, var. Gum Creek
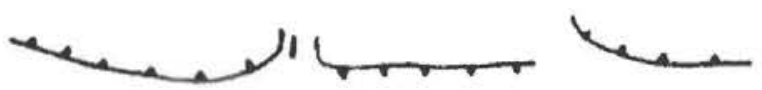

Discontinuous scroll with tick marks; lip notched

Figure 2. Two different kinds of Womack Engraved vessels (including var. Gum Creek) in Gum Creek cluster sites and an example of Simms Engraved, var. Darco. 
Harleton Appliqued jar

Wilder Engraved

Cass Appliqued jar

Taylor Engraved

Karnack Brushed-Incised

Frank Smith (see Perttula 2006a:33-40, 93-96)

Ripley Engraved

Taylor Engraved

Ripley Engraved with inverted rim

Chalice

Womack Engraved, var. Gum Creek (see Figure 2)

Harleton Appliqued

Womack Engraved, semi-circles

Wilder Engraved bottle/olla

Cass Appliqued

Herbert Taft (41UR320, see Perttula 2006a:68-75)

Ripley Engraved

Harleton Appliqued

Hodges Engraved (with suspension holes)

Taylor Engraved

Cass Appliqued

Bailey Engraved
Natchitoches Engraved (suspension holes)

Womack Engraved, meandering scroll

Galt knife (large chipped knives

also from Sword sitc, 41UR208)

Henry Williams (41UR318, see Perttula 2006a:86-88, 93)

Talco points

Ripley Engraved

Glass beads (large blue, red-white, Cornaline d'aleppo, ca. 1700-1760)

Hawkbell, var. Flushloop

Starr Site (41UR319, see Perttula 2006a:88-90)

Taylor Engraved

Ripley Engraved

Henry Spencer (41UR315, see Perttula 2006a: 107-108)

Hodges Engraved shouldered jar/suspension holes (cf. 41UR2, J. M. Riley site vessel, see Suhm and Jelks 1962:Plate 38a)

Spool-necked bottles

Hodges Engraved double bowl

Medium-large white, red, blue, green, and black glass beads 
Womack Engraved vessels with inverted rims are present in three of the sites, including a vessel at the Herbert Taft with a characteristic meandering scroll. Two other varieties of Womack are also noted: (a) vessels decorated with a series of engraved concentric semi-circles (see Figure $2 a$ ), and (b) other vessels with engraved concentric semi-circles, central dots or dashes, and small pendant triangles. We have defined this as Womack Engraved, var. Gum Creek (see Figure 2b).

Particular attention and renewed scrutiny should be paid in the analysis of decorated fine ware vessels in Caddo sites in the Cypress, upper Sabine, and upper Sulphur river drainages to identify with certainty these more distinctive vessel forms and engraved motifs that hint at post A.D. 1670/1680 Caddo occupations, especially when European trade goods might not be present in the assemblages being studied. Womack Engraved is still a poorly understood ceramic type, and mis-affiliated with Norteno focus occupations by groups thought to be affiliated with the Wichita by some archaeologists (cf. Jelks 1967; Johnson and Jelks 1958).

We are of the opinion that Womack Engraved is a southern Caddo ceramic type that may represent a stylistic development in form and decoration from either or both Ripley Engraved and Taylor Engraved. It is the inverted rim form that is especially characteristic of the type as we conceive it (though both Taylor and Ripley Engraved vessels with inverted rims are known from the area, see Perttula and Green [2006: Figure $4]$ ), along with the use of engraved pendant triangles, semi-circles, and meandcring scrolls. Such vessels occur with Ripley and Taylor Engraved vessels at more than a handful of sites in the Cypress, upper Sabine (Cast et al. 2006: Figures 3f, 39-40), and upper Sulphur river basins, and we seriously doubt that the Nortenos were responsible for their manufacture or deposition in what amount to very late Titus phase graves.

\section{References Cited}

Cast, R., T. K. Perttula, B. Gonzalez, and B. Nelson

2006 Documentation of Caddo Ceramic Vessels from 41 WD60, Wood County, Texas. Texas Parks \& Wildlife Department, Austin, and Historic Preservation Program, Caddo Nation of Oklahoma, Binger, Oklahoma.

Jelks, E. B. (editor)

1967 The Gilbert Site: A Norteno Focus Site in Northeast Texas. Bulletin of the Texas Archeological Society 37:1-248.

Johnson, L., Jr. and E. B. Jelks

1958 The Tawakoni-Yscani Village, 1760: A Study in Site Identification. Texas Journal of Science 10(4):405-422. 
Perttula, T. K.

2005 (Editor) Archeological Investigations at the Pilgrim's Pride Sile (4ICP304), a Titus Phase Communily in the Big Cypress Creek Basin, Camp Counly, Texas. 2 Vols. Report of Investigations No. 30. Archeological \& Environmental Consultants, LLC, Austin.

2006a A Study of the Buddy Jones Collection from Northeast Texas Caddo Sites. Special Publications No. 6. Friends of Northeast Texas Archaeology, Austin and Pittsburg.

$2006 \mathrm{~b}$ The Structure and Growth of a Titus Phase Community Cemetery in Titus County, Texas. Journal of Northeast Texas Archaeology 25:1-18.

Perttula, T. K., with contributions by T. E. Emerson and R. E. Hughes $200541 \mathrm{HO} 64 / 41 \mathrm{HO} 65$, Late $17^{\text {th }}$ to Early $18^{\text {th }}$ Century Caddo Sites on San Pedro Creek in Houston County, Texas. Bulletin of the Texas Archeological Society 75:85-103.

Perttula, T. K. and L. Green

2006 Marine Shell Ear Disks from Protohistoric Caddo Sites on Stouts Creek, Hopkins County, Texas. Joumal of Northeast Texas Archaeology 25:19-25.

Suhm, D. A. and E. B. Jelks (editors)

1962 Handbook of Texas Archeology: Type Descriptions. Special Publication No. I, Texas Archeological Society, and Bulletin No. 4, Texas Memorial Museum, Austin. 